Como citar este artículo:

Bolívar, E., Coronado, O., García, C. \& Hernández, J. (2020). Enforced disappearances and

social services: reconstruction of the Ayotzinapa, Iguala, Guerrero (central Mexico) case. Revista

Eleuthera, 22(1), 149-171 DOI: 10.17151/eleu.2020.22.1.9.

\title{
ENFORCED DISAPPEARANCES AND SOCIAL SERVICES: RECONSTRUCTION OF THE AYOTZINAPA, IGUALA, GUERRERO (CENTRAL MEXICO) CASE*
}

\section{DESAPARICIONES FORZADAS Y SERVICIOS SOCIALES: RECONSTRUCCIÓN DEL CASO AYOTZINAPA, IGUALA, GUERRERO (MÉXICO CENTRAL)}

\author{
JORGE HERNÁNDEZ-VALDÉS** \\ Cruz García-Lirios*** \\ Eyder Bolivar-MOJICA**** \\ OSCAR CORONADO-RINCÓN*****
}

\begin{abstract}
Objective. Social historical reconstruction of the Ayotzinapa case from the perspective of Social Work intervention models. Methodology. Mixed, a qualitative, retrospective and hermeneutical study with key informants and other quantitative, cross-sectional and correlational research with an intentional selection of mobilization activists in favor of Ayotzinapa. Results. Disclosure of meanings from discourses and narratives of causal attribution of responsibility to the State for the enforced disappearance and genocide of 43 students, as well as relationships that determine the expectations of justice based on the expectations of honesty. Conclusion. The intersection device corresponds to a qualitative and quantitative diagnosis of the social representations of the Ayotzinapa case spread as a central axis of a public agenda.
\end{abstract}

Key words: Ayotzinapa, enforced disappearances, historical memory, social services

\section{Resumen}

Objetivo. Hacer una reconstrucción histórica social del caso de Ayotzinapa desde la perspectiva de los modelos de intervención de Trabajo Social. Metodología. Estudio mixto, cualitativo, retrospectivo y hermenéutico con informantes clave y otra investigación cuantitativa, transversal y correlacional con una selección intencional de activistas de movilización a favor de Ayotzinapa. Resultados. Divulgación de

\footnotetext{
* Work derived from the project: "Forced dissapearance: prospective interventions of the TS" financed by the Red Académica Transdisciplinar, registration number: ATN-2019-CGL-0001

** Universidad Nacional Autónoma de México. México D.F., México. E-mail: jorheval@unam.mx.

(1) orcid.org/0000-0001-6490-0479 Google Scholar

*** Universidad Autónoma del Estado de México. Huehuetoca, Estado de México, México. E-mail: cgarcial213@profesor. uaemex.mx. (1) orcid.org/0000-0002-9364-6796 Google Scholar

**** Universidad Santo Tomas. Bogotá, Colombia. E-mail: eyder.bolivarmo@ustamed.edu.co

(D) orcid.org/0000-0002-4144-0921 Google Scholar

**** Universidad de Sonora. Sonora, México. E.mail: oscar.coronado@unison.mx

(D) orcid.org/0000-0003-3651-6896 Google Scholar
} 
Enforced disappearances and social services: reconstruction of the Ayotzinapa, Iguala, Guerrero (Central Mexico) case

significados de discursos y narrativas de atribución causal de responsabilidad al Estado por la desaparición forzada y el genocidio de 43 estudiantes, así como relaciones que determinan las expectativas de justicia basadas en las expectativas de honestidad. Conclusión. El dispositivo de intersección corresponde a un diagnóstico cualitativo y cuantitativo de las representaciones sociales del caso de Ayotzinapa extendido como eje central de una agenda pública.

Key words: Ayotzinapa, desapariciones forzadas, memoria histórica, servicios sociales.

\section{Introduction}

At 5:30 p.m., on September 26, 2014, a group of 80 students from a teacher training rural college got organized to attend the commemorative demonstrations of the so-called Matanza de Tlatelolco on October 2, 1968 in Mexico City. The meeting point was the center of the municipality of Iguala, Guerrero in the Southeast of Mexico. At 9:30 p.m. municipal, state and federal police attacked the buses that transported the students. At 10:30 p.m. a bus was blocked in front of the municipal government building, 43 students were attacked and disappeared by federal, state and municipal police (Grupo Interdisciplinario de Expertos Independientes, 2014).

Enforced disappearances can be analyzed from the Historical Memory. The social representations that allude to the central meanings of public security and the peripheral symbols of violence have revealed objectification structures (general ideas) and anchoring (appropriation and use) that can be observed in the Ayotzinapa case (Schulz, 2015).

From SocialWork and, in particular, from its approach to violence and security, the reconstruction of historical memory and its intervention with enforced disappearances such as the case of the 43 students of Ayotzinapa, Iguala, Guerrero (central Mexico ), can be analyzed from the objectification and anchoring of the facts disseminated in the media (Pavón-Cuellar, 2015).

The objective of this study is to explain the social representations around the case of the 43 students who disappeared the night of September 26, 2014. Although six people died and 25 were injured, the social imaginary focuses on the kidnapped teacher-training college students.

\section{The rectory of the State around security}

The scenarios that legitimize the State are known as risks, threats and vulnerability. Security policies are identified as territorial security, national security, public safety, citizen security and private security (Dehdezi \& Sardi, 2016) due to their degree of prevention and targeting. Each of the three scenarios is not only linked to security policies, but also to others that set the guidance of the State. 
The rectory of the State can be observed at different levels whenever its propaganda, agenda, representation and trust are analyzed as effects of security policies on citizenship (see Table 1).

Table 1. Effects of the rectory of the State in matters of security

\begin{tabular}{|c|c|c|c|c|}
\hline Security & Propaganda & Schedule & Representation & Trust \\
\hline Territorial & $\begin{array}{l}\text { The absolutist } \\
\text { state spreads its } \\
\text { function as a divine } \\
\text { representative that } \\
\text { materializes in the } \\
\text { care of its patrimony } \\
\text { in order to legitimize } \\
\text { its power over the } \\
\text { subjects }\end{array}$ & $\begin{array}{l}\text { The issue of } \\
\text { surveillance is } \\
\text { preponderant in } \\
\text { security policy. }\end{array}$ & $\begin{array}{l}\text { The surveillance of } \\
\text { the State is symbolized } \\
\text { by the subjects as a } \\
\text { guarantee of their } \\
\text { security. }\end{array}$ & $\begin{array}{l}\text { The subjects depend } \\
\text { emotionally on the } \\
\text { warlike capacity of the } \\
\text { State. }\end{array}$ \\
\hline National & $\begin{array}{l}\text { The State includes } \\
\text { citizens in the } \\
\text { demarcation of their } \\
\text { borders, spreading } \\
\text { the idea of union } \\
\text { between the ruler } \\
\text { and the governed } \\
\text { people. }\end{array}$ & $\begin{array}{l}\text { The theme of } \\
\text { union and identity } \\
\text { is hegemonic in the } \\
\text { discourse of the } \\
\text { ruler }\end{array}$ & $\begin{array}{l}\text { Identity is symbolized } \\
\text { by the governed } \\
\text { people as a guarantee } \\
\text { of internal pacification } \\
\text { and external } \\
\text { belligerence. }\end{array}$ & $\begin{array}{l}\text { The governed people } \\
\text { depend on the } \\
\text { persuasive capacity of } \\
\text { their rulers }\end{array}$ \\
\hline Public & $\begin{array}{l}\text { The State recognizes } \\
\text { the importance of } \\
\text { its management and } \\
\text { administration of } \\
\text { public life, respecting } \\
\text { the privacy of its } \\
\text { governed people. }\end{array}$ & $\begin{array}{l}\text { Public and private } \\
\text { issues are essential } \\
\text { in the State-citizen } \\
\text { relationship. }\end{array}$ & $\begin{array}{l}\text { Privacy is symbolized } \\
\text { as a right and the } \\
\text { public is an imaginary } \\
\text { of conformity and } \\
\text { obedience. }\end{array}$ & $\begin{array}{l}\text { Citizens depend on } \\
\text { the management and } \\
\text { public administration } \\
\text { of the State. }\end{array}$ \\
\hline Citizen & $\begin{array}{l}\text { The State } \\
\text { disseminates and } \\
\text { facilitates the } \\
\text { autonomy of citizens } \\
\text { with respect to their } \\
\text { security organization } \\
\text { capabilities. }\end{array}$ & $\begin{array}{l}\text { The issues } \\
\text { concerning human } \\
\text { rights are a priority } \\
\text { in security policy. }\end{array}$ & $\begin{array}{l}\text { Human rights are } \\
\text { symbolized as a } \\
\text { guarantee of defense } \\
\text { against the power of } \\
\text { the State }\end{array}$ & $\begin{array}{l}\text { Citizens become } \\
\text { independent } \\
\text { from management, } \\
\text { but not from the State } \\
\text { security administration }\end{array}$ \\
\hline Private & $\begin{array}{l}\text { The State delegates } \\
\text { its own security } \\
\text { to the individual, } \\
\text { contributing to its } \\
\text { uses and customs } \\
\text { in the prevention } \\
\text { of crime and self- } \\
\text { defense of their } \\
\text { property and private } \\
\text { life. }\end{array}$ & $\begin{array}{l}\text { The issues of } \\
\text { self-defense and } \\
\text { crime prevention } \\
\text { are central to the } \\
\text { government's } \\
\text { discourse. }\end{array}$ & $\begin{array}{l}\text { Self- } \\
\text { defense is symbolized } \\
\text { as an independence } \\
\text { of the individual from } \\
\text { the State }\end{array}$ & $\begin{array}{l}\text { Individuals dispense } \\
\text { with state security } \\
\text { forces. }\end{array}$ \\
\hline
\end{tabular}


Enforced disappearances and social services: reconstruction of the Ayotzinapa, Iguala, Guerrero (Central Mexico) case

Although the rectory of the State assumes different degrees of security policies in the face of risks, threats and vulnerabilities, it is possible to notice that dialogue and co-responsibility between the governors and the governed people; the latter seem to distance themselves from the actors by virtue of the fact that private security is replacing the other forms of security (Ramos, 2005). Within the framework of public and citizen security, the difference between spending on security and the crime rate could encourage not only the asymmetries between security policies and social representations of security, but also an imaginary in which the rectory of the State vanishes and is replaced by private security.

The rectory of the State can be indicated by the amount of the budget destined for security, but if the crime rate reaches high percentages with respect to the sample of inhabitants, then the budget indicator vanishes before the galloping increase of the crimes (Tumas \& Janusauskas, 2013). Based on these discrepancies between security spending and the crime rate, a social representation of the loss of the rectory of the State is forged, which would be indicated by low levels of perceptions and expectations regarding freedom, morality, repression, censorship, dissidence, decency, leadership and justice.

Since the perception of inefficiency and ineffectiveness around security policies is based on the destined expense, the citizenry develops an imaginary that symbolizes the State as a corrupt, indecent, negligent, immoral, nepotistic and repressive instance lacking leadership and management skills as well as administration of the security forces and, consequently, as a producer of injustice (Aguirre \& Muggah, 2017). The distrust of citizens in authorities derives not only from the social representations of its lost rectory, but also from the capacity of selforganization and self-management of civil sectors in terms of their private security.

The legitimacy of the rectory of the State is questioned and, therefore, symbolized as a corrupt instance, since it delegates responsibilities to the civil sectors organized in self-defense or selfmanagement of their own private security (Guerrero, 2007). In this scenario of risk, threat and vulnerability of political and social actors, the events of humanity or enforced disappearance evidence the absence of the ruling State and the emergence of social representations as indicators of the self-organization of civil society.

\section{Theory of Media Representations}

The project was encouraged by contemporary discussions about the attention to victims as a pending issue in social policies and services for peacemaking with an emphasis on victim care (Feáns, 2015).

However, it was necessary to establish the social representations around the 43 disappeared teacher training college students, since these arise from the establishment of a public agenda by spreading a social imaginary centered on rhetorical figures such as "they were taken alive, we want them alive", or, "it was the State" (Robledo y Velazquez, 2017). 
That is to say that the event has had such a scope that it was not only an event of global mobilization in favor of the victims, the relatives of the 43 disappeared teacher training college students, but also an official propaganda of the State that focuses its interest in demonstrating "the historical truth" has been generated as well as the emergence of counter-propaganda focused on demonstrating the responsibility of local and federal government (Fernández, 2015).

Both announcements have been disseminated in the national and international media, promoting the emergence of a social thought in which justice is synonymous with live presentation of the disappeared, or the demarcation of responsibilities of political actors (Espinoza, 2019).

Therefore, both advertisements formed a public agenda in which the central themes were 1) the live presentation of the disappeared, 2) the demarcation of responsibilities, 3) the credibility of the state's propaganda and the counter-propaganda of civil society and 4) the legitimacy of the expert versions, but the attention to victims seems to be a peripheral issue (Rivas, 2014).

While social and mediatic political actors have focused on the plausibility of the tests with the purpose of defining responsibilities and launching accusations, the relatives and friends of the 43 disappeared have been left out of the case (Slimovich y Lay Arellano, 2018).

Such situation is of great importance for Social Work because this discipline measures conflicts between political and social actors, but when the media are involved, the study of social representations implies a more accurate diagnosis (Martiny y Reynoso, 2016).

Crimes against humanity are often addressed by their political essence, since the State is conceptualized as a Leviathan capable of procuring security and preventing crime, as well as guaranteeing social peace, excluding social actors (Taibi, 2016).

Social Work is, hence, the discipline devoted to the study of conflicts between governors and the governed people with respect to public safety and social peace with an emphasis on victim assistance through mediation. The history of the discipline evidences its development, which ranges from considering civil society as defenseless people to assuming them as protagonists of their security.

Regarding the State, the discipline of social work has advanced in its analysis from the rectory of public security to the investigation of its corruption, negligence, opacity, nepotism or discretion processes that inhibit the construction of social peace, national reconciliation or the vindication of violated sectors.

Based on these considerations, this report presents the history of the rectory of the State in security matters, reviewing territorial, national, public, citizen and private security models in order to discuss their relevance in the case of the 43 teacher training college students disappeared (Fernández, 2018) 
Enforced disappearances and social services: reconstruction of the Ayotzinapa, Iguala, Guerrero (Central Mexico) case

Next, the events of the Ayotzinapa case are chronologically described to establish the axes and central themes in the agendas of the media, their relationship with the public opinion and the establishment of the public agenda on security issues (Gómez, 2015a).

Subsequently, the results of the study are presented following a hypothetical deductive logic about how the social representations of the sample surveyed are derived from the systematic dissemination of the topics established in the public agenda on the Ayotzinapa case (Gravante, 2018).

Therefore, in the subsequent chapter the intervention models of Social Work are presented with the purpose of discussing their scope and limits in the solution of the conflict and the construction of a public peace agenda, as well as the recognition of the victims and their mourning process (Gómez, 2015b).

Finally, an alternative solution to the conflict between the authorities and dissident sectors of civil society is offered through a mediation device, although irreconcilable positions are observed between security policies and civil initiatives, pacification is a latent scenario that can be reached with the help of political, social and media actors.

\section{Method}

From the theory of social representations and the theory of the establishment of the agenda as explanatory conceptual axes of historical memory, enforced disappearances represent a multidisciplinary approach.

The objectification (generalized idea of the Ayotzinapa case) and the anchorage (generalized practice of attribution of responsibility to the State) combine with the framework (enforced disappearance and genocide of the State) of the media.

That is, the historical memory of the Ayotzinapa case is a media construction reduced to the responsibility of the State as responsible for enforced disappearance and genocide. Thus, the reconstruction of such media process suggests an analysis of the symbols, meanings and meanings of representation (objectification and anchoring) and the setting of the facts in the establishment of the agenda (State responsible for the disappearance and genocide).

Therefore, a qualitative and quantitative study was carried out in three phases.

\section{First phase}

A documentary investigation was conducted on the discourses of experts and non-experts regarding the Ayotzinapa case, considering its dissemination in national and international media, as well as the representation of each social sector. They were: an expert in human rights and enforced disappearances (Judge Baltazar Garzón), an academic expert (Boaventura de Souza Santos) and three representatives of participatory civil society. 
The information was processed following the technique of analyzing discourse symptoms, as well as its comparison in three rounds; the first one concerning the emptying of information, the second one alluding to the concatenation of the data and the third one referring to the differences between the informants with respect to the sectors they represent.

A qualitative data analysis software was used, following the objectification and anchoring of the theory of social representations and the informative framing of the theory of the establishment of the agenda.

\section{Second stage}

An exploratory, cross-sectional and correlational study was conducted with a sample of 105 students from a public university in central Mexico, considering their activism in the Ayotzinapa case and their exposure to media, as well as their participation in protest mobilizations and support for the families of the disappeared.

Based on the results of the first phase of the present work, the Media Representation Scale was built. It included 32 items related to eight conceptual dimensions that derive from the Ayotzinapa case, the objectification and the anchoring of the State as responsible for the disappearance and the genocide. Each reagent is answered with one of five options that range from "nothing probable" to "totally probable".

The surveys were carried out at the public university facilities, provided to guarantee anonymity and confidentiality of the responses, as well as data protection and non-impact on the academic status of the respondents.

The statistical analysis package for social sciences version 25 was used, considering the measurement of normality, reliability, validity, correlation and adjustment of the model in order to test the null hypothesis of significant differences between the discursive theoretical dimensions with respect to the observed dimensions.

\section{Third phase}

The findings of the first phase were compared with the results of the second phase to establish the axes and discussion topics objectified and anchored around the Ayotzinapa case, following the Delphi technique with expert judges in the study of enforced disappearances and genocide.

\section{Results}

\section{The framing of the Ayotzinapa case}

If the studies of the State rectory in matters of security show the formation of a social representation in accordance with political corruption and collusion with organized crime 
Enforced disappearances and social services: reconstruction of the Ayotzinapa, Iguala, Guerrero (Central Mexico) case

by the law enforcement institutions, then the case of the 43 missing students is framed in the imaginary of justice for the genocide attributed to the municipal, state and federal presidency.

These are symbolizations that develop different meanings around the loss of rectories of the State and the emergence of citizen security as well as private security that replace the territorial, national and public security scheme.

If the social representation of the Ayotzinapa case, considers the framing as a systematic process of establishing topics, then it will be possible to analyze its agenda centered on the figurative core or centrality of the images and contents with respect to the figurative belt or periphery of symbols and meanings around an event.

The media analysis of the Ayotzinapa case, centered on the journalistic agenda, highlights a parallelism between government actions and social mobilization. Both are oriented towards the demarcation of responsibilities from a trusted scientific source, although the Austrian Innsbruck Laboratory (LIA), the Independent Expert Investigators Group (GIEI) and the Argentine Forensic Anthropology Team (EAAF) do not always agree with the discourse of the government.

The agenda established by the Excelsior newspaper of national circulation in the Ayotzinapa case focuses on the contradiction of the investigations, experiments and evidence regarding the murder and incineration of the 43 missing teacher training college students (see Table 2).

Table 2. Media agenda of the Ayotzinapa case

\begin{tabular}{|c|c|c|c|}
\hline Date & Event & Centrality & Periphery \\
\hline $\begin{array}{l}26-I X- \\
2014\end{array}$ & $\begin{array}{l}\text { Attack of the police to } \\
\text { teacher training college } \\
\text { students }\end{array}$ & $\begin{array}{l}6 \text { dead } 25 \text { injured and } 46 \\
\text { missing }\end{array}$ & Police violence \\
\hline $\begin{array}{l}28-I X- \\
2014\end{array}$ & Detention of 22 policemen & 22 policemen indicted & Police Corruption \\
\hline $\begin{array}{l}30-I X- \\
2016\end{array}$ & Leak of the Mayor of Iguala & José Luis Abarca fugitive, mayor & Political Negligence \\
\hline $\begin{array}{l}4-X- \\
2014\end{array}$ & The PGR attracts the case & Attorney General's Office & Federal relevance \\
\hline $\begin{array}{l}17-X- \\
2014\end{array}$ & Capture of intellectual author & $\begin{array}{l}\text { Sinodrio Covarrubias capo from } \\
\text { "Guerreros Unidos" }\end{array}$ & $\begin{array}{l}\text { Demarcation of } \\
\text { responsibilities }\end{array}$ \\
\hline $\begin{array}{l}22-X- \\
2014\end{array}$ & $\begin{array}{l}\text { The PGR blames the local } \\
\text { president and his wife }\end{array}$ & José Luis Abarca fugitive, mayor & Local political corruption \\
\hline $\begin{array}{l}23-X- \\
2014\end{array}$ & Governor resignation & Ángel Aguirre, governor & $\begin{array}{l}\text { Demarcation of } \\
\text { responsibilities }\end{array}$ \\
\hline $\begin{array}{l}29-X- \\
2014\end{array}$ & $\begin{array}{l}\text { Meeting of victims with the } \\
\text { president }\end{array}$ & Enrique Peña Nieto, president & Search intensification promise \\
\hline $\begin{array}{l}7-X I- \\
2014\end{array}$ & $\begin{array}{l}\text { Official death of the } 43 \\
\text { disappeared }\end{array}$ & $\begin{array}{l}\text { Cocula wastebasket, scene of } \\
\text { murder and incineration }\end{array}$ & Assassins Confessions \\
\hline
\end{tabular}




\begin{tabular}{|c|c|c|c|}
\hline Date & Event & Centrality & Periphery \\
\hline $\begin{array}{l}7-X I I- \\
2014\end{array}$ & $\begin{array}{l}\text { First laboratory } \\
\text { identification of Innsbruck, } \\
\text { Austria }\end{array}$ & $\begin{array}{l}\text { Alexander Mora, first identified } \\
\text { teacher training college student }\end{array}$ & Expert relevance \\
\hline $\begin{array}{l}27-I- \\
2015\end{array}$ & $\begin{array}{l}\text { Conference of the "Historical } \\
\text { Truth" }\end{array}$ & $\begin{array}{l}\text { Jesús Murillo Karam, former } \\
\text { prosecutor }\end{array}$ & $\begin{array}{l}\text { Murder and Incineration in } \\
\text { the Cocula dump }\end{array}$ \\
\hline $\begin{array}{l}1-I I I- \\
2015\end{array}$ & IACHR designates the GIEI & $\begin{array}{l}\text { Interdisciplinary } \\
\text { Group of Independent Experts }\end{array}$ & Research from Human Rights \\
\hline $\begin{array}{l}16-I X- \\
2015\end{array}$ & $\begin{array}{l}\text { Second laboratory } \\
\text { identification of Innsbruck, } \\
\text { Austria }\end{array}$ & $\begin{array}{l}\text { Jhosivani Guerrero, second } \\
\text { identified teacher training } \\
\text { college student }\end{array}$ & $\begin{array}{l}\text { Expert, social and political } \\
\text { relevance }\end{array}$ \\
\hline $\begin{array}{l}24-I X- \\
2015\end{array}$ & $\begin{array}{l}\text { Special Prosecutor for the } \\
\text { Search of Disappeared }\end{array}$ & Care for victims & Policy for victims \\
\hline $\begin{array}{l}30+X I- \\
2015\end{array}$ & $\begin{array}{l}\text { Special Prosecutor's Office } \\
\text { for the Search of the } 43 \\
\text { missing teachers }\end{array}$ & Care for victims & Victim care policy \\
\hline $\begin{array}{l}9-I I- \\
2016\end{array}$ & $\begin{array}{l}\text { Opinion of the Argentine } \\
\text { Forensic Anthropology Team }\end{array}$ & $\begin{array}{l}\text { Null signs of murder and } \\
\text { incineration in the Cocula } \\
\text { landfill }\end{array}$ & Scientific relevance \\
\hline $\begin{array}{l}1-I V- \\
2016\end{array}$ & $\begin{array}{l}\text { New expertise in the dump } \\
\text { of Cocula }\end{array}$ & Disqualification of the GIEI & $\begin{array}{l}17 \text { teacher training college } \\
\text { students were incinerated in } \\
\text { the dump }\end{array}$ \\
\hline $\begin{array}{l}19-V I I I- \\
2016\end{array}$ & $\begin{array}{l}\text { Relatives break dialogue with } \\
\text { the State }\end{array}$ & $\begin{array}{l}\text { Tomas Cerón, director } \\
\text { of the Criminal } \\
\text { Investigation Agency }\end{array}$ & $\begin{array}{l}\text { Requirements of dismissal of } \\
\text { the director }\end{array}$ \\
\hline $\begin{array}{l}13-I X- \\
2016\end{array}$ & $\begin{array}{l}\text { Incineration experiment } \\
\text { reverses the murder and } \\
\text { incineration of the } 43 \text { teacher } \\
\text { training college students in } \\
\text { the Cocula dump }\end{array}$ & $\begin{array}{l}\text { José Torero, forensic expert in } \\
\text { incineration }\end{array}$ & $\begin{array}{l}\text { Experimental scientific } \\
\text { relevance }\end{array}$ \\
\hline $\begin{array}{l}14-I X- \\
2016\end{array}$ & $\begin{array}{l}\text { Resignation of the } \\
\text { director of the Criminal } \\
\text { Investigation Agency }\end{array}$ & Tomas Cerón, agency director & Staff rotation policy \\
\hline
\end{tabular}

Source: prepared based on the newspaper Excelsior

It is noticeable that in the case of the Excelsior, the agenda of the disappearance of the 43 teacher training college students of Ayotzinapa is not centered on the victims except in the case of the last events related to the creation of the Specialized Prosecutor's Office for the Search of Disappeared (FEBD) and the Special Prosecutor's Office for the Search of Young People (FEBJ).

However, discourses prevail over the Ayotzinapa case, which consider it an event against humanity, a genocide, or a process of political impunity characteristic of the Mexican state. 
Enforced disappearances and social services: reconstruction of the Ayotzinapa, Iguala, Guerrero (Central Mexico) case

\section{Discourses on the Ayotzinapa case}

Crimes against humanity are symbolized according to a figurative nucleus; in the case of Ayotzinapa, a sample of statements of actors of different sexes, age and socioeconomic status warn: "The genocide is not far from Mexico. So how can you call them what happened to the teacher training college students? We are facing crimes against humanity" (Objetivo en línea, 2015, p. 10). "What human rights commissions are those that exist in that country, which are absent and ignored in the face of crimes against humanity while the real human rights activists are murdered?" (Santos, 2014, p. 11).

The statements of these actors of recognized prestige in terms of analysis of human rights and justice show a figurative nucleus focused on the categorization of the Ayotzinapa case as a crime against humanity, which contrasts with the social representation of the actors of society civil.

\footnotetext{
It was the state that has historically been able to face an unprotected section of the people against their own co - religionists. The Mexican state is capable of confronting society against society itself. (22-year-old student activist, personal communication, September 30, 2014)

I think it was the State, since I can remember I've heard that the government has persecuted and murdered students, so I think Ayotzinapa is the same as Tlatelolco. (52-year-old urban merchant, personal communication, September 30, 2014)

Who else but the State? No one can disappear without the State knowing or executing the disappearance. The cartels and the criminals are their employees, just like the hitmen or drug traffickers. (49-year-old female head of family, personal communication, September, 30, 2014)
}

In other words, the social representation of the Ayotzinapa case focuses on the guilt attributed to the State, but not only because of the magnitude and impact of the event that, but also because each of the events seems to be related to the perceived authoritarianism of civil society with respect to its rulers. This event is qualified by experts as a crime against humanity and it would be up to the citizens to imagine the omnipresence of the State,

Therefore, the category of responsibility of the State as a perpetrator of crimes against humanity, in the case of expert discourses, suggests a causal attribution bias to associate an event with a political actor that reflects its authoritarian historicity.

In contrast, the discursive positioning of non-experts towards the political actor consists rather in the identification of symbols that would be associated with their repression policy and that has not only been observed by the citizen, but also recognized as their hallmark with respect to other actors.

Both discourses by experts and non-experts in human rights, those of an authoritarian State and those of a pervasive State, combine with the media discourse that frames the State in its 
security propaganda contrary to the propaganda of insecurity built by the GIEI and GAAF.

\section{Social representations of the 43 missing students}

Table 3 and Table 4 show the social representations of the 43 teacher training college students weighted from eight dimensions relative to repression expectations (alpha reliability of 0.881 and $27 \%$ of the total variance explained), perceived morality (alpha of 0.885 and 19). \% of the total variance explained), expectation of censorship (alpha of 0.882 and $17 \%$ of the total variance explained), expected freedom (alpha of 0.887 and 13\% of the total variance explained), expected critical (alpha of 0.884 and $9 \%$ of the total variance explained), expected decency (alpha of 0.883 and $7 \%$ of the total variance explained), leadership (alpha of 0.883 and $5 \%$ of the total variance explained) and expected justice (0.882 and 3\% of the total variance explained).

Table 3. Descriptions and reliability of the instrument

\begin{tabular}{|c|c|c|c|c|}
\hline $\mathrm{R}$ & Subscale / reagent & $M$ & $D$ & $A$ \\
\hline & Expectancy subscale repression & & & 0.881 \\
\hline$r 1$ & The State will imprison kidnappers & 4.23 & 0.42 & 0.802 \\
\hline$r 2$ & The State will disappear those who investigate kidnappings & 4.81 & 0.32 & 0.805 \\
\hline$r 3$ & The State will censor those who report kidnappings & 4.02 & 0.46 & 0.814 \\
\hline \multirow[t]{2}{*}{$r 4$} & Those who support victims of kidnappings will be co-opted & 3.69 & 0.38 & 0.825 \\
\hline & Subscale of perceived Morality & & & 0,885 \\
\hline$r 5$ & A State that protects its citizens prevents kidnappings & 4.05 & 0.49 & 0.806 \\
\hline r6 & Kidnappings are only seen in dictatorships & 4.16 & 0,51 & 0.816 \\
\hline$r 7$ & A Security State resolves kidnappings & 4.38 & 0.24 & 0.815 \\
\hline \multirow[t]{2}{*}{ r8 } & Kidnappings are indicative of public insecurity & 4.89 & 0.42 & 0.812 \\
\hline & Censorship Expectation Subscale & & & 0.882 \\
\hline r9 & Protests for kidnappings will be broadcasted as violent & 3.91 & 0.59 & 0.802 \\
\hline r10 & Kidnappings will be disseminated as local crimes & 4.37 & 0.53 & 0.843 \\
\hline$r 11$ & The dissemination of kidnappings will be seen as political propaganda & 4.06 & 0.59 & 0.813 \\
\hline \multirow[t]{2}{*}{$r 12$} & Kidnappings will be reported as passion crimes & 4.16 & 0.59 & 0.825 \\
\hline & Subscale of Freedom expected & & & 0.887 \\
\hline r13 & Kidnappings will open public discussion & 3.71 & 0.41 & 0.813 \\
\hline r14 & Expressions against kidnappings will inhibit their proliferation & 3.05 & 0.32 & 0.832 \\
\hline$r 15$ & Kidnappings will open eyes to potential victims & 4.37 & 0.59 & 0.851 \\
\hline \multirow[t]{2}{*}{ r16 } & Denunciations of kidnappings will allow an expeditious police search & 3.26 & 0.43 & 0.862 \\
\hline & Critical subscale expected & & & 0.884 \\
\hline$r 17$ & $\begin{array}{l}\text { The rectory of State will be questioned if the kidnappings are not } \\
\text { resolved }\end{array}$ & 4.36 & 0.12 & 0.805 \\
\hline$r 18$ & The kidnappings are a presage of social censure for the president & 4.01 & 0.24 & 0.824 \\
\hline$r 19$ & $\begin{array}{l}\text { The distrust towards the State will be permanent if it does not solve } \\
\text { the kidnappings }\end{array}$ & 4.37 & 0.24 & 0.831 \\
\hline r20 & Kidnappings are indicative of ungovernability & 4.37 & 0.16 & 0.852 \\
\hline
\end{tabular}


Enforced disappearances and social services: reconstruction of the Ayotzinapa, Iguala, Guerrero (Central Mexico) case

\begin{tabular}{|c|c|c|c|c|}
\hline $\mathrm{R}$ & Subscale / reagent & $M$ & $D$ & $A$ \\
\hline & Decency subscale expected & & & 0.888 \\
\hline r21 & Political corruption will inhibit the resolution of kidnappings & 4.43 & 0.31 & 0.814 \\
\hline$r 22$ & Kidnappings will be solved by negligent politicians & 4.65 & 0.24 & 0.842 \\
\hline r23 & Political opacity will promote kidnappings & 4.49 & 0.47 & 0.825 \\
\hline \multirow[t]{2}{*}{$r 24$} & Kidnappings will be resolved by political nepotism & 4.83 & 0.32 & 0.836 \\
\hline & Perceived Leadership Subscale & & & 0,883 \\
\hline$r 25$ & The kidnappings will be resolved by the candidates for the presidency & 4.39 & 0.15 & 0.815 \\
\hline$r 26$ & The next president will solve the kidnappings & 4.78 & 0.32 & 0.832 \\
\hline$r 27$ & The kidnappings will be resolved by the future mayor of the city & 3.27 & 0.28 & 0.852 \\
\hline \multirow[t]{2}{*}{$r 28$} & The next attorney will resolve the kidnappings & 4.38 & 0.37 & 0.862 \\
\hline & Justice Sub-Scale expected & & & 0.882 \\
\hline$r 29$ & Kidnappings will require a "zero tolerances" strategy & 4.49 & 0.32 & 0.814 \\
\hline r30 & Crime prevention will be the strategy to follow regarding kidnappings & 4.42 & 0.25 & 0.821 \\
\hline$r 31$ & Kidnappings will be resolved in full compliance with the law & 4.69 & 0.32 & 0.832 \\
\hline$r 32$ & $\begin{array}{l}\text { The delivery of justice around kidnappings will be guaranteed by the } \\
\text { State }\end{array}$ & 4.40 & 0.41 & 0.845 \\
\hline
\end{tabular}

Source: prepared with the study data

The general reliability of the scale (alpha of 0.881 ) shows an adequate internal consistency and the validity of the construct shows an adequacy and sphericity $\left.\int \chi^{2}=234 / 45 \mathrm{gl}\right) \mathrm{p}=0.000$; $\mathrm{KMO}=0.613 \mathrm{~J}$ that allowed the estimation of the eight factors discussed.

Table 4. Validity of the instrument

\begin{tabular}{|c|c|c|c|c|c|c|c|c|c|}
\hline$R$ & Subscale / reagent & $F 1$ & $F 2$ & $F 3$ & $F 4$ & $F 5$ & F6 & $F 7$ & F8 \\
\hline & Expectancy subscale repression & & & & & & & & \\
\hline $\mathrm{r} 1$ & The State will imprison kidnappers & 0.451 & & & & & & & \\
\hline r2 & $\begin{array}{l}\text { The State will disappear those who } \\
\text { investigate kidnappings }\end{array}$ & 0.406 & & & & & & & \\
\hline$r 3$ & $\begin{array}{l}\text { The State will censor those who } \\
\text { report kidnappings }\end{array}$ & 0.482 & & & & & & & \\
\hline \multirow[t]{2}{*}{$r 4$} & $\begin{array}{l}\text { Those who support victims of } \\
\text { kidnappings will be co-opted }\end{array}$ & 0,491 & & & & & & & \\
\hline & Subscale of perceived Morality & & & & & & & & \\
\hline$r 5$ & $\begin{array}{l}\text { A State that protects its citizens } \\
\text { prevents kidnappings }\end{array}$ & & 0.303 & & & & & & \\
\hline r6 & $\begin{array}{l}\text { Kidnappings are only seen in } \\
\text { dictatorships }\end{array}$ & & 0.336 & & & & & & \\
\hline$r 7$ & $\begin{array}{l}\text { A Security State resolves } \\
\text { kidnappings }\end{array}$ & & 0.391 & & & & & & \\
\hline \multirow[t]{2}{*}{$r 8$} & $\begin{array}{l}\text { Kidnappings are indicative of public } \\
\text { insecurity }\end{array}$ & & 0.385 & & & & & & \\
\hline & Censorship Expectation Subscale & & & & & & & & \\
\hline$r 9$ & $\begin{array}{l}\text { Protests for kidnappings will be } \\
\text { broadcasted as violent }\end{array}$ & & & 0.401 & & & & & \\
\hline
\end{tabular}




\begin{tabular}{|c|c|c|c|c|c|c|c|c|c|}
\hline$R$ & Subscale / reagent & $F 1$ & $F 2$ & F3 & F4 & F5 & F6 & $F 7$ & F8 \\
\hline$r 10$ & $\begin{array}{l}\text { Kidnappings will be disseminated as } \\
\text { local crimes }\end{array}$ & & & 0.482 & & & & & \\
\hline r11 & $\begin{array}{l}\text { The dissemination of kidnappings } \\
\text { will be seen as political propaganda }\end{array}$ & & & 0.474 & & & & & \\
\hline \multirow[t]{2}{*}{$r 12$} & $\begin{array}{l}\text { Kidnappings will be reported as } \\
\text { passion crimes }\end{array}$ & & & 0.485 & & & & & \\
\hline & Subscale of Freedom expected & & & & & & & & \\
\hline$r 13$ & $\begin{array}{l}\text { Kidnappings will open public } \\
\text { discussion }\end{array}$ & & & & 0.383 & & & & \\
\hline$r 14$ & $\begin{array}{l}\text { Expressions against kidnappings will } \\
\text { inhibit their proliferation }\end{array}$ & & & & 0.386 & & & & \\
\hline $1 \mathrm{r} 5$ & $\begin{array}{l}\text { Kidnappings will open eyes to } \\
\text { potential victims }\end{array}$ & & & & 0.305 & & & & \\
\hline \multirow[t]{2}{*}{$r 16$} & $\begin{array}{l}\text { Denunciations of kidnappings will } \\
\text { allow an expeditious police search }\end{array}$ & & & & 0.391 & & & & \\
\hline & Critical subscale expected & & & & & & & & \\
\hline$r 17$ & $\begin{array}{l}\text { The rectory of State will be } \\
\text { questioned if the kidnappings are } \\
\text { not resolved }\end{array}$ & & & & & 0,486 & & & \\
\hline r18 & $\begin{array}{l}\text { The kidnappings are a presage of } \\
\text { social censure for the president }\end{array}$ & & & & & 0.456 & & & \\
\hline$r 19$ & $\begin{array}{l}\text { The distrust towards the State will } \\
\text { be permanent if it does not solve the } \\
\text { kidnappings }\end{array}$ & & & & & 0.437 & & & \\
\hline \multirow[t]{2}{*}{ r20 } & $\begin{array}{l}\text { Kidnappings are indicative of } \\
\text { ungovernability }\end{array}$ & & & & & 0.472 & & & \\
\hline & Decency subscale expected & & & & & & & & \\
\hline $2 \mathrm{r} 1$ & $\begin{array}{l}\text { Political corruption will inhibit the } \\
\text { resolution of kidnappings }\end{array}$ & & & & & & 0.461 & & \\
\hline$r 22$ & $\begin{array}{l}\text { Kidnappings will be solved by } \\
\text { negligent politicians }\end{array}$ & & & & & & 0.476 & & \\
\hline$r 23$ & $\begin{array}{l}\text { Political opacity will promote } \\
\text { kidnappings }\end{array}$ & & & & & & 0.437 & & \\
\hline \multirow[t]{2}{*}{$r 24$} & $\begin{array}{l}\text { Kidnappings will be resolved by } \\
\text { political nepotism }\end{array}$ & & & & & & 0,491 & & \\
\hline & Perceived Leadership Subscale & & & & & & & & \\
\hline$r 25$ & $\begin{array}{l}\text { The kidnappings will be resolved by } \\
\text { the candidates for the presidency }\end{array}$ & & & & & & & 0,396 & \\
\hline$r 26$ & $\begin{array}{l}\text { The next president will solve the } \\
\text { kidnappings }\end{array}$ & & & & & & & 0.302 & \\
\hline$r 27$ & $\begin{array}{l}\text { The kidnappings will be resolved by } \\
\text { the future mayor of the city }\end{array}$ & & & & & & & 0.357 & \\
\hline \multirow[t]{2}{*}{$r 28$} & $\begin{array}{l}\text { The next attorney will resolve the } \\
\text { kidnappings }\end{array}$ & & & & & & & 0.351 & \\
\hline & Justice Sub-Scale expected & & & & & & & & \\
\hline$r 29$ & $\begin{array}{l}\text { Kidnappings will require a "zero } \\
\text { tolerances" strategy }\end{array}$ & & & & & & & & 0.327 \\
\hline$r 30$ & $\begin{array}{l}\text { Crime prevention will be the } \\
\text { strategy to follow regarding } \\
\text { kidnappings }\end{array}$ & & & & & & & & 0.326 \\
\hline
\end{tabular}


Enforced disappearances and social services: reconstruction of the Ayotzinapa, Iguala, Guerrero (Central Mexico) case

\begin{tabular}{|c|c|c|c|c|c|c|c|c|c|}
\hline$R$ & Subscale / reagent & $F 1$ & $F 2$ & $F 3$ & $F 4$ & $F 5$ & F6 & $F 7$ & $F 8$ \\
\hline$r 31$ & $\begin{array}{l}\text { Kidnappings will be resolved in full } \\
\text { compliance with the law }\end{array}$ & & & & & & & & 0.365 \\
\hline r32 & $\begin{array}{l}\text { The delivery of justice around } \\
\text { kidnappings will be guaranteed by } \\
\text { the State }\end{array}$ & & & & & & & & 0.378 \\
\hline
\end{tabular}

Extraction method: main axes, promax rotation, exploratory factor analysis. Adequacy and sphericity $\{\chi 2=234 / 45 \mathrm{gl}) \mathrm{p}=0.000 ; \mathrm{KMO}=0.613\} . \mathrm{M}=$ Mean, $\mathrm{SD}=$ Standard Deviation, Alpha $=$ Internal consistency of the subscale, $\mathrm{F} 1=$ Expression of repression ( $27 \%$ of the total variance explained), F2 = Perceived morality (19\% of the total variance explained), F3 = Expectation of censorship (17\% of the total variance explained), F4 = Expected freedom (13\% of the total variance explained), F5 = Expected criticism $(9 \%$ of the total variance explained), F6 = Expected decency (7\% of the total variance explained), F7 = Perceived leadership ( $5 \%$ of the total variance explained), F8 = Justice expected ( $3 \%$ of the total variance explained).

Source: prepared with the study data

The covariance between exogenous factors shows significant, but spurious relationships between perceived morality and expectations of censorship (0.051, p0.008), perceived morality with expectations of repression $(0.176, \mathrm{p}=0.041)$ and expectations of censorship with repression of expectations $(0.144, \mathrm{p}=0.034)$.

In the case of the dependency relations between the factors, the decency perceived with the perceived morality stands out (0.308: $\mathrm{p} 0.38)$.

Table 5. Correlations and covariances between the factors

\begin{tabular}{|c|c|c|c|c|c|c|c|c|c|c|c|c|c|c|c|c|}
\hline & $F 1$ & $F 2$ & $F 3$ & $F 4$ & $F 5$ & F6 & $F 7$ & $F 8$ & $F 1$ & $F 2$ & $F 3$ & $F 4$ & $F 5$ & F6 & $F 7$ & $F 8$ \\
\hline$F 1$ & 1.0 & $54 *$ & $62 * *$ & $68 * * *$ & $52 * * *$ & , $41 * *$ &, $65 *$ &, $50 *$ & 1.9 &, 52 &, 59 & , & 52 &, 53 &, 52 & 60 \\
\hline$F 2$ & & 1.0 &, $51 *$ &, $60 *$ &, $46 * *$ &, $44 *$ & $62 * *$ &, $52 * *$ & & 1,8 &, 63 & 55 & , 66 &, 62 & 55 & , 66 \\
\hline F3 & & & 1.0 &, $59 *$ &, $37 *$ &, $40 *$ &, $49 *$ &, $55 *$ & & & 1.6 & , & 60 &, 65 &, 47 & , 53 \\
\hline F4 & & & & 1.0 &, $39 *$ &, $65 * *$ &, $48 *$ & $53 * * *$ & & & & 1.7 & 58 & 60 &, 59 & , 58 \\
\hline$F 5$ & & & & & 1.0 & $48 * * *$ &, $37 *$ &, $63 *$ & & & & & 1,8 & , 48 &, 58 & , 51 \\
\hline F6 & & & & & & 1.0 &, $47 *$ &, $40 * *$ & & & & & & 1,5 &, 67 & , 48 \\
\hline$F 7$ & & & & & & & 1.0 &, $52 * *$ & & & & & & & 1.9 & , 49 \\
\hline F8 & & & & & & & & 1.0 & & & & & & & & 1.4 \\
\hline
\end{tabular}

F1 = Expression of repression, F2 = Perceived morality, F3 = Expectation of censorship, F4 = Expected freedom, F5 = Expected criticism, F6 = Expected decency, F $7=$ Perceived leadership, F8 = Expected justice: *<, $01 \quad ; * * \mathrm{p}<001 \quad ; * * * \mathrm{p}$ $<, 0001$

Source: prepared with the study data 
In this way, the structural model $\lceil\chi 2=456(341 \mathrm{gl}) \mathrm{p}=0.0132$; GFI $=0.970$; $\mathrm{CFI}=$ $0.975 ;$ RMSEA $=0,000 \mathrm{~J}$ evidence as a predictor of perceived justice to the expected criticism.

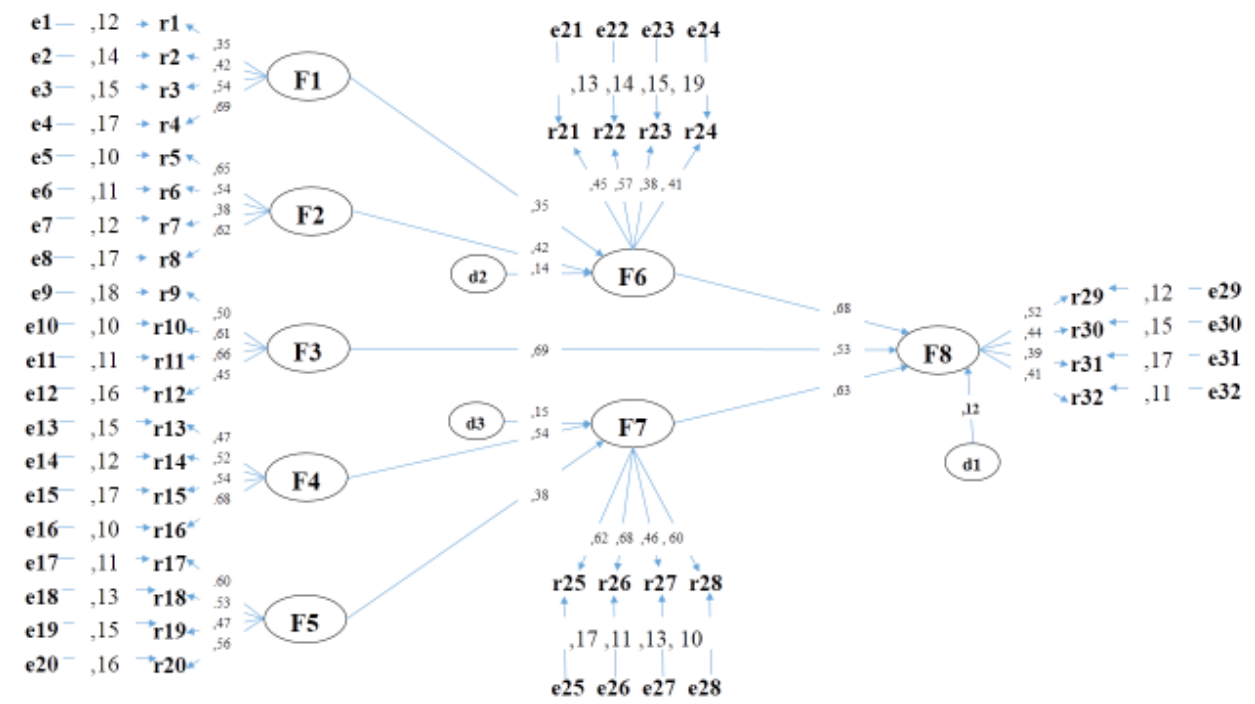

Figure 1. Social representations of justice

F1 = Expression of repression, F2 = Perceived morality, F3 = Expectation of censorship, F4 = Expected freedom, F5 = Expected criticism, F6 = Expected decency, F7 = Perceived leadership, F8 = Expected justice: $\mathrm{d}=$ Disturbance measured factor, e $=$ Error measured indicator: ç relations between disturbances or indicators with respect factors or indicators; è relations between factors and indicators

Source: prepared with the study data

These data indicate that the social representations of the Ayotzinapa case are centered on the absence of criticism towards the State and the expectations of justice, as is the case of the clarification of the kidnapping of the 43 teacher training college students.

Therefore, the construction of a public peace, centered on caring for victims, would not be created from the establishment of a civil agenda indicated by issues of debate and negotiation agreements for the claim and emancipation, but rather the process of pacification would emerge from the absence of a critical, deliberate, planned and systematic rationality for the defense of human rights. 


\section{Discussion}

\section{Prolegomena of the public peace}

Within the framework of the rectory of the State as a prosecutor of crime and provider of justice, the construction of public peace, from organized civil society, is critical of security policies, crime prevention programs and strategies to combat crime.

However, the media have focused their agenda on the violence of the State, police corruption, political negligence, the demarcation of responsibilities, the promise of intensification of the search for the 43 teacher training college students, the confession of the perpetrators, the relevance of the expert evidence, the incineration evidence of 17 teacher training college students in the Cocula dump, the Human Rights approach, the victim care policy, the relevance of incineration experiments and the rotation policy of case officials Ayotzinapa

The framing of media has not focused on issues that allow the formation of a social representation aimed at a debate on the relationship between governors and the governed people with respect to the Ayotzinapa case. That is, citizens do not have enough information to engage in a discussion that allows reaching a negotiation and agreements with their authorities for the construction of a pacification pact at the local, state or federal level.

Consequently, the differences around the narratives and the discourses of experts and nonexperts reflect the agenda of the media around the Ayotzinapa case and show significant differences that move away from a debate of co-responsibility between governed people and governors. While experts categorize the Ayotzinapa case as a crime against humanity and the citizenship creates an attribution of guilt to the State, the dialogue between political and social actors seems to be increasingly distant in the absence of points of agreement that are rather antagonistic.

The process that goes from the propaganda of the rectory of the State to the distrust of the citizenry towards its rulers reflects a scenario of symbolic violence rather than pacification. Therefore, not only the state's propaganda should be modified to include the citizenry as a victim of the Ayotzinapa case, but also the violation of human rights should be accompanied by an agenda to clarify the facts by recognized academic figures.

Such a measure would generate a social representation of the Ayotzinapa case centered on the search for a common good between public actors and social, but it would also have repercussions on the trust of civil society towards its authorities and institutions in charge of investigating the kidnapping of 43 teacher training college students.

In a scenario in which citizens have expectations of repression (27\% of the total variance explained in the empirical study) instead of the perceived freedom (13\% of the total variance explained), 
there is at least one symbolic conflict between the civil and the political. Such a scenario inhibits debate and agreements and encourages differences between rulers and governed people.

The repression that citizens expect from their authorities affects their perceived freedom and this is affected by an immorality that determines the criticism and this affects a decent behavior, also reducing the emergence of leadership and impacting perceived justice.

Therefore, the construction of a public peace from the propaganda, the agenda, the representations and the trust among the actors seems to be inhibited at least by factors that attempt against the negotiation between the rulers and the governed people, since if the first caused fear, fear and indignation in citizens and they generate opinion leaders based on rules and moral values far from a critical rationality. Then, we witness a scenario in which public peace would be the result of a non-aggression agreement among the actors, rather than being the product of a deliberate, planned and systematic system for the prosecution of crime, the prevention of violence, the delivery of justice and the defense of human rights.

From this scenario it is pertinent to review the proposals for intervention that, from Social Work have been generated with the purpose of promoting human relations free from violence, to inhibit crime and conflicts between citizens and authorities.

\section{Models of Social Work for victim assistance}

Since its inception Social Work has generated models to promote the rectory of the State, or promote civil self-management. The history of the discipline has influenced the development of intervention models. In the welfare stage, the State generated welfare policies that Social Work assumed as categorical imperatives of health, education and employment, following guidelines of coverage to groups and civil sectors, the discipline was led to produce models that contributed to the strengthening of corporatism.

This is how Social Work included in its intervention some economic and political models as well as social factors such as the dissemination of family planning campaigns, or in any case, the adherence to the treatment of diseases that, due to their degree of impact on society, were considered epidemics or pandemics, threatening the economic dynamics of the nation. In this historical period, the State sought territorial security and from that logic, it strengthened the family as the central axis of public services.

Both items, vaccination and planning were no more than synonyms of security and social welfare that legitimized the control of health and safety institutions by the State. As a new generation of politicians considered that processes and products of public service should be an exclusive patrimony of families of officials, the Welfare State allowed a patrimonialist state very close to the neoliberal or gendarme that, until then, had the rectory of security no longer territorial or national, but public. 
Enforced disappearances and social services: reconstruction of the Ayotzinapa, Iguala, Guerrero (Central Mexico) case

In the scheme of territorial security, Social Work conceived models focused on the prevention of conflicts and national identity. Therefore, during the campaigns in favor of caudillos and revolutionary nationalism, the discipline generated models that focused on reproducing the differences between nationalism and foreignness represented by the United States. Although the migratory flows intensified, Social Work was not interested in guiding such flows towards a defense of human rights, not even towards the occupational health of migrants who were hired under working conditions unfavorable to their dignity.

Regarding national security policies that emphasized national identity, bypassing other foreign, indigenous or Afro-descendent identities, the discipline showed little interest in promoting the values of a post-civil war nation. Rather, the task was to promote adherence to a hegemonic party to the detriment of other political options. Thus, socialist models that emphasized solidarity and cooperation were eradicated from the national identity scenario to be replaced by corporatist models at the economic and political levels. The nascent chambers, groups and unions around the caudillos and the postrevolutionary state denied forms of social entrepreneurship and rather oriented the civil will to dependence, obedience and conformity to the presidential political system.

However, once the welfare state entered into economic crises that undermined its patrimony unexpectedly, the political class generated a patrimonialist ideology that consisted in preserving every emblem, process, function or resource used by a family of officials during the period of the postrevolutionary state (1920-1970). Patrimonialism generated new forms of relations between rulers and the governed people, fostering the reproduction of differences between political and social actors.

Through the intensive diffusion of a propaganda in favor of the rectory of the State in matter of well-being, Social Work is aligned with what Foucault (2002, 2004, 2005, 2007) calls positivity device, which consists of the use of academic, scientific and technological knowledge as instruments of legitimation of public policies of the State (Gros et al., 2005).

Thus, the welfare state acquired a patrimonial tinge in which important positions of public administration were discretionally determined by the president, but now they would be decided from the offices of intermediate officials with a preferential bias towards friends and family.

In terms of efficiency and effectiveness in public administration, the State dissociated itself from its social welfare objective and implemented targeted programs and strategies that would benefit groups of adherents and sympathizers of its political ideology.

The patrimonialist State, unlike the Welfare State, dissociated itself from social demands and needs, but focused on the expectations and requirements of the political class whose objective was to establish significant differences with respect to civil society. 
Once the patrimonial model secured its goods and processes of public administration, a gradual transformation began until acquiring a neoliberal face that consisted in the dismantling of parastatal institutions, the reduction of social programs and the implementation of an institutional evaluation for those instances linked to the government budget.

The new neoliberal State, once again conducive to a Social Work oriented to the evaluation of the opportunities and capacities of sectors marginalized or excluded from civil society, as well as the brake on cooperative or socialist organization and development options.

If the Welfare State Social Work was advocated to promote national identity and in the patrimonial State the discipline promoted civil participation through adherence to political institutions sponsored by the State, now in the neoliberal State Social Work generated models and instruments of evaluation that allowed it to orient the budgets to sectors identified with the propaganda of the State.

However, the defense of human rights progressed towards an incidence in the policies of attention to victims that, in the case of citizen security, is an instrument of governmental performance. Unlike the territorial, national and public security policies that sought national unity for the prevention of crime and the construction of violence-free relations, citizen security considers the conservation of values and norms by promoting an ethical morality of cooperation and solidarity.

In the framework of citizen security, State management instruments allow civil selfmanagement, but as technologies develop, civil security becomes a private security. In both cases, for citizens and private security, Social Work has generated intervention models focused on the individual rather than on groups, heritage, the nation or the territory.

Models centered on the individual deny the possibility that citizens get organized in groups of observation, management and action in favor of common security. As a consequence, the discipline faces the dilemma of returning to its origins in which it carried out diagnoses and promoted safety as a result of a social question and common interest before the possibility of reducing its models to the learning of self-care skills and knowledge and contact avoidance.

\section{Intervention and intercession devices}

A device is a concept that explains a process of reproduction of the differences between governors and the governed people with respect to security, demands and resources, opportunities and the capacities of management and administration of security policies, prevention programs and strategies of promotion.

In the conception of Foucault $(2002,2004,2005,2007)$ the device has a high content of positivity, that is to say, knowledge about a phenomenon such as security. 
Enforced disappearances and social services: reconstruction of the Ayotzinapa, Iguala, Guerrero (Central Mexico) case

Therefore, a security device is one in which a governing class takes advantage of all possible knowledge regarding a scenario, group or environment to be differentiated from the governed people.

If in the stage of social welfare, the device was implemented to distribute the resources among the different civil sectors. Now, in the neoliberal period, the device seeks differences among civil sectors to implement a specific control of their opportunities and capacities. The union that was previously promoted from Social Work is now seen as a problem of operation in the designation of resources, since these are increasingly scarce and in order to be distributed with equity some sectors must progressively pay higher rates, some other sectors will receive subsidies and other sectors will benefit from the cancellation of the payment of security services.

Therefore, since Social Work has developed models of intercession or mediation of conflicts when public policies generate differences among the actors that produce conflicts for the management of security.

An intervention model promotes differences or seeks to reduce them, correcting the asymmetries, but an intercession model intensifies the differences or similarities by engaging in negotiation among the parties in order to achieve a balance of risks, threats and benefits.

As a result, the intervention model of Social Work would consist of the reduction of citizen security and the increase of private security, since the principle that the State and the citizens form a co-government and reach an agreement of co-responsibility such that civil society no longer depends on police or military forces, but rather generates a civilian figure capable of protecting it. In this scenario, private security is hegemonic with respect to other forms of security and the intervention model seeks to select the talents that will make up the new security body.

In the model, the negotiation between civil networks and political institutions revolves around security such as values, beliefs, knowledge, intentions, dialogues, consensus and actions aimed at building public peace through crime prevention management and promotion of violencefree lifestyles, as well as the delivery of justice through a concerted decision-making system between political and social actors.

In contrast, an intercession model would rather focus on the transfer of virtues of the actors to a public or private security scenario.

In the case of the intercession model, the governance or governance of civil networks and political spheres is mediated by Social Work specialized in conflict resolution. The process is similar to that of the intervention device, but it is assumed that there is a co-responsibility independent of the needs and capacities of the political and social actors. 


\section{Final considerations}

This report has addressed the Ayotzinapa case from a multidisciplinary approach with the purpose of proposing two models for intervention and intercession among the interests of the actors involved. In this way, the management and administration of citizen and private security takes place based on the differences between the rulers and the governed people, but also from the history of the discipline. Thus, the diagnosis of the Ayotzinapa case with respect to the social representation of the actors determines the intervention or intercession of Social Work, considering neoliberal policies rather than social welfare or patrimonial.

Within the framework of political neoliberalism, the diagnosis of social representations contributes to the construction of public peace, reducing the differences among the actors and rescuing the virtues of state management and social self-management, both synthesized in a socio-governmental co-management or governance of citizen and private security.

\section{References}

Aguirre, K. \& Muggah, R. (2017). Agencies and “citizen security” approach in Latin America. Revista cidob d'afers internacionals, 25-52.

Dehdezi, A. K. \& Sardi, F. K. Q. (2016). The Role of Public Security in Society. International Journal of Humanities and Cultural Studies (IJHCS), 2090-2096.

Espinoza, M. (2019). 43 de Ayotzinapa: imagen, signo y multitud. Discurso Visual, 43, 81-88.

Feáns, A. Á. (2015). Necrología incómoda de México: la náusea de los crímenes de Iguala. Revista Internacional de Comunicación y Desarrollo (RICD), 1(1), 181-185.

Fernández, A. M. (2015). Una mirada social general sobre el movimiento por Ayotzinapa. Teknokultura, 12 (2), 241-265.

Fernández, A. M. (2018). Crónica de una movilización anunciada: todos somos Ayotzinapa. Revista de Ciencias Sociales, 161, 25-41

Foucault, M. (2002). The archeology of knowledge. Buenos Aires, Argentina: Siglo XXI.

Foucault, M. (2004). Watch and punish. Buenos Aires, Argentina: Siglo XXI.

Foucault, M. (2005). The hermeneutics of the subject: lectures at the Collège de France, 1981-1982.

Recovered from http://rebels-library.org/files/foucault_hermeneutics.pdf

Foucault, M. (2007). Birth of biopolitics. México D. F., Mexico: FCE.

Gómez, M. (2015a). Ayotzinapa de la crisis humanitaria a la crisis del Estado. El Cotidiano, 189, 50-59. 
Enforced disappearances and social services: reconstruction of the Ayotzinapa, Iguala, Guerrero (Central Mexico) case

Gómez, G. V. (2015b). Derecho a la verdad: estudiantes desaparecidos en Ayotzinapa, México. Anuario de Derechos Humanos, (11), 107.

Gravante, T. (2018). Desaparición forzada y trauma cultural en México: el movimiento de Ayotzinapa. Convergencia, 25 (77), 13-28.

Gros, F., Foucault, M., Burchell, G., Ewald, F., Fontana, A. \& Davidson, A. I. (2005). The Hermeneutics of the Subject: Lectures at the College de France, 1981-1982. New York: Palgrave Macmillan.

Grupo Interdisciplinario de Expertos Independientes -GEI-. (2015). Ayotzinapa, G. I. Investigación y primeras conclusiones de las desapariciones y homicidios de los normalistas de Ayotzinapa. Recuperado de https://www.oas.org/es/cidh/actividades/giei/GIEIboletin-2015-09-06.pdf.

Guerrero, L. F. (2007). Seguridad pública y prevención del delito en el Estado social de derecho. Especial comentario a la trascendencia de la educación. Díkaion, 16(1).

Martiny, M. L. y Reynoso, Z. O. (2016). Ayotzinapa: Nuestro Retrato Frente al Espejo. Acta Sociológica, 71, 167-193.

Objetivo en línea. (2015). Baltazar Garzón habla sobre la investigación de los 43 desaparecidos de Ayotzinapa Mexico. 「Video file J. Retrieved from https://www.youtube.com/ watch?v $={ }_{z R} 9 E W 23 i j t Y$

Pavón-Cuéllar, D. (2015). Ayotzinapa en la psicología: del sentimiento momentáneo al acontecimiento histórico. Teoría y Crítica de la Psicología, (5), 194-202.

Ramos, J. M. (2005). Seguridad ciudadana y la seguridad nacional en México: hacia un marco conceptual. Revista Mexicana de Ciencias Políticas y Sociales, 47(194), 33-52.

Rivas, P. (2014). Todos somos Ayotzinapa. Educere, 18 (61), 577-588.

Robledo, C. y Velásquez, E. P. (2017). La desaparición de los 43 normalistas en México: una aproximación al análisis crítico del discurso en la prensa. rev. colomb. cienc. soc., 8 (2) 272 570 .

Santos, B de S. (2014). Carta a las y los jóvenes de México. La Jornada. Recuperado de https: / / www.jornada.com.mx/2014/11/16/politica/009a1pol.

Schulz, C. (2015). Ayotzinapa / México: Documentación y análisis de un crimen a la luz de un marco jurídico internacional sobre la desaparición forzada. Berlín, Alemania: México vía Berlín e. V. y Partner Südmexikos e. V.

Slimovich, A. y Lay Arellano, I. T. (2018). La reacción ciudadana en la sociedad hipermediática contemporánea. El caso de la movilización por los estudiantes mexicanos desaparecidos de Ayotzinapa. PAAKAT: revista de tecnología y sociedad, 7(13). 
Taibi, P. S. (2016). La desaparición forzada de los normalistas de Ayotzinapa. Una tragedia para reflexionar desde la óptica del sistema interamericano de protección de los derechos humanos. Derecho y Justicia, (7), 97-126.

Tumas, V. \& Janušauskas, A. (2017). New challenges for public security. Retrieved from https:// repository.mruni.eu/handle/007/14914 